\title{
高速液体クロマトグラフィーによるワイン中の総アスコルビン酸, 総エリソルビン酸，ソルビン酸の同時迅速定量法
}

\author{
柳田顕郎・橋本昭洋・黄木信夫 \\ (ニッカウキスキー〈株〉生産技術研究所)
}

平成 2 年 6 月 27 日受理

A Method of Simultaneous Rapid Determination for Total Ascobate, Total Erythorbate and Sorbic Acid in Wine by High Performance Liquid Chromatography

Akio Yanagida, Akihiro Hashimoto and Nobuo OUKI

(Institute for Production Research and Development Nikka Whisky Distilling Co. Ltd., 967, Aza-Matsuyama, Masuo, Kashiwa-shi, Chiba, 277, Japan)

A method of simultaneous rapid determination for total ascorbate, total erythorbate and sorbic acid in wine was developed by using high performance liquid chromatography (HPLC) with ultraviolet (UV) detection.

Wine sample which contained each additive was treated with a Sep-pak CN cartridge, and then dehydroascorbic acid (DHAA) and dehydroerythorbic acid (DHEA) in flow-through fraction were reduced by dithiothreitol (DTT) to ascorbic acid (AA) and erythorbic acid (EA), respectively. The reduction was completed in $15 \mathrm{~min}$ at room temperature. The resulting total $\mathrm{AA}$, total EA and sorbic acid (SA) in this fraction were resolved on a DEVELOSIL- $\mathrm{NH}_{2}$ column, and detected by UV $(268 \mathrm{~nm})$ absorption. The detection limits of these additives in wine were $3 \mathrm{mg} / \mathrm{kg}$. The coefficients of variation $(n=5)$ were $2.8 \%$ for total AA $(50 \mathrm{ppm}), 2.0 \%$ for total EA (50 ppm) and $3.5 \%$ for $\mathrm{SA}(50 \mathrm{ppm})$ in spiked wine.

Key words : アスコルビン酸・高速液体クロマトグラフィー・ワイン

\section{緒言}

食品中のアスコルビン酸 (AA) の定量に関しては, イ ンドフェノール滴定法1やヒドラジン比色法1などが一 般に用いられているが，1）共存物質の妨害を受けやす い，2）操作がやや繁雑という欠点があるため，近年で は高速液体クロマトグラフィー（HPLC）を用いたより 迅速かつ感度・選択性を向上させた手法が発達してきて いる。

HPLC 法では, 当初 AA とその酸化型であるデヒ ドロアスコルビン酸（DHAA）を分離して定量する手 段 ${ }^{2 \sim 4}$ が選択されたが，紫外部吸収 (UV) で同時検出す る際の DHAA の感度が非常に悪いため, 現在では 1) $\mathrm{AA}$ を酸化剂で DHAA に転換した後,プレまたはポス トカラムの段階で DHAA を蛍光誘導体化して蛍光検出 する方法 ${ }^{2}$ 10)，2）DHAA を還元剂で AA に転換した 後, $\mathrm{AA}$ を UV 検出する方法 ${ }^{11 \sim 14)}$, の 2 通りの定量手段
が主流となっている。1）の方法は非常に高感度である 反面, 誘導体化に伴う操作・装置の必要性という点にお いて 2）ょり迅速性・一般性に久ける。2）の方法は 1) より検出感度は劣るが簡便・迅速である。

HPLC 法ではまた，AA とその立体異性体であるエり ソルビン酸 (EA) を分離し, 同時定量することが可能で ある ${ }^{7,10,12,15)}$ 。この場合, 酸化あるい:還元処理を行って やることで， $\mathrm{AA} \rightleftarrows \mathrm{DHAA}$ の場台と全く同様に還元型 (EA) 酸化型 (DHEA) の転換が起こるため, 総 AA と総 $\mathrm{EA}$ が同時定量できる。

以上，概説の測定手段の向上に伴い，今日では非常に 多岐にわたる食品試料中の AA， EA の定量が行われて いる。一方， ワインの AA 分析に関しては O.I.V. (Office International de la Vigne et du Vin)による方

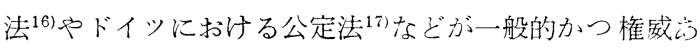
る方法とされているが、これら公定法は先述のインドフ エノール滴定法を採用して拈り，HPLC 法による分析例 
は未だ報告されていないのが現状である。我が国では平 成元年 2 月 20 日の酒税法施行規則改正により果実酒へ の AA の添加（酸化防止剂）が認められたこと,ならび に平成 3 年 7 月 1 日以降製造される製品については食 品添加物の新表示が義務付けられること,などを考虑す るとワイン中の AA， EA の簡便な定量法を確立するこ とは重要かつ急務であると考兄られる。

以上の観点を踏まえつつ,さらに $\mathrm{AA}$ と $\mathrm{EA}$ の極大 吸収波長 $\left(\lambda_{\max }=268 \mathrm{~nm}\right)$ がワインの保存料隹使用され るソルビン酸 $(\mathrm{SA})$ の極大吸収波長 $\left(\lambda_{\max }=254 \mathrm{~nm}\right)$ と 接近していることに着目し, 今回, HPLC/UV 検出法に よるワイン中の総 $\mathrm{AA}$, 総 $\mathrm{EA}$ ならびに $\mathrm{SA}$ の同時迅速 定量法を確立したので以下に報告する。

\section{実 験 方 法}

\section{1. 試薬ならびに試液}

エリソルビン酸, ソルビン酸カリウム, リン酸 2 水素 1 カリウム, リン酸 1 水素 2 カリウム: 関東化学(株)製 特級品

アスコルビン酸，ジチオスレイトール（DTT)，高速 液体クロマトグラフィー用アセトニトリル：MERCK 社製

デヒドロアスコルビン酸：ALDRICH 社製

水: NANOPURE II (BARNSTEAD 社製) 精製超純 水

$10 \mathrm{mM}$ DTT 含有還元試液： $10 \mathrm{mM}$ リン酸緩衝液 （pH 7.0）とアセトニトリルを $1: 3$ の比率で混合し全 量を $100 \mathrm{ml}$ とした後, DTT $0.154 \mathrm{~g}$ を同溶液で溶解 し試液とした。本試液は $0.45 \mu \mathrm{m}$ のフィルターで濾過 し, 氷点下で保存した。

\section{2. 装置ならびに器材}

高速液体クロマトグラフ：Waters 社製 600 マルチソ ルベント送液システム、

注入装置：Waters 社製 712 WISP サンプルプロセッ サー

UV/VIS 検出器: 相馬光学(株)製 S-3702

インテグレーター: Waters 社製 741 データモジュー ル

Sep-pak $\mathrm{C}_{18}, \mathrm{CN}$, accell $\mathrm{CM}$ カートリッジ：Waters 社製

メンブランフィルター：東洋濾紙(株)製，DISMIC$25 \mathrm{cs}, \quad 0.45 \mu \mathrm{m}$

\section{3. 試験溶液の調製}

クリーンアップ：あらかじめメタノール，蒸留水名 $10 \mathrm{~m} l$, 西るい烝留水 $10 \mathrm{ml}$ (accell $\mathrm{CM}$ の場合) でュ ンディショニングされた Sep-pak カートリッジに， ワ
イン試料 $5 \mathrm{~m} l$ をゆっくり通過させた。この際, 溶出し てくる最初の $2.5 \mathrm{~m} l$ を捨てて残りを分取し, $0.45 \mu \mathrm{m}$ のフィルターを通過させて微粒子を除いた。

還元操作：クリーンアップした試料の $0.5 \mathrm{ml}$ を分取

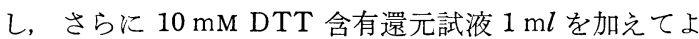
く擋はんした。混合液を 15 分間放置した後, 試験溶液 として HPLC 分析に供した。

\section{HPLC による定量}

試験溶液 $15 \mu l$ をPLC に導入してピーク面積を求 め, あらかじめ作成した検量線から総 $\mathrm{AA}$ ，総 $\mathrm{EA} な ら$ びに SA の濃度を算出した。

HPLC 条件は以下のと扔りとした。

分離カラム：野村化学(株)製 DEVELOSIL $\mathrm{NH}_{2}-5$ $(4.6 \mathrm{~mm} \phi \times 150 \mathrm{~mm})$

移動相溶媒 : $10 \mathrm{mM}$ リン酸 2 水素 1 カリウムーアセ卜 ニトリル $(1: 3)$

カラム温度 : $30^{\circ} \mathrm{C}$

流速 : $1.0 \mathrm{ml} / \mathrm{min}$

検出波長 : $268 \mathrm{~nm}$

\section{実験結果および考察}

\section{1. 移動相組成}

AA，EA，SA の各濃度を $50 \mathrm{ppm}$ として調製した標 準溶液（溶媒：移動相溶媒）を用いて，各成分がクロマ トグラム上に打いて分離されるような HPLC の移動相 条件を検討した結果, $10 \mathrm{mM}$ リン酸 2 水素 1 カリウムー アセトニトリル (1:3) の組成で Fig.1 亿示したような 良好な分離が得られた。

\section{DTT による還元効果の確認}

本法では各成分の検出方法に UV を採用したため, あらかじめ試料中の DHAA をAAに，季たDHEAを

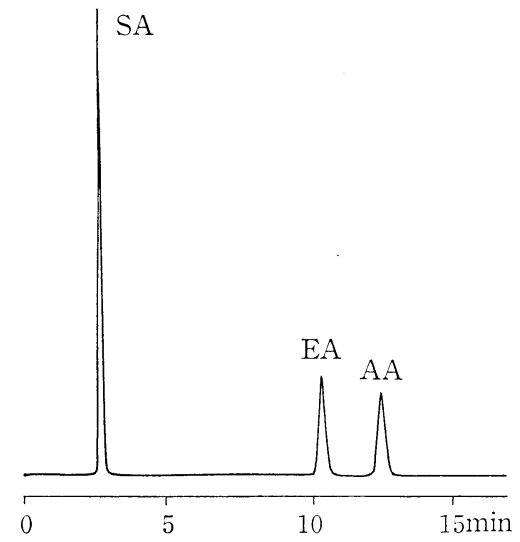

Fig. 1 Chromatogram of standard ascorbic acid (AA), erythorbic acid (EA) and sorbic acid (SA). 
柳田・橋本・黄木：高速液体クロマトグラフィーによるワイン中の総アスコルビン酸等の同時迅速定量法

EA に還元した後に総 $\mathrm{AA}$ ，総 EA 量を定量する手段が 有効となる。還元試薬としてはホモシステイン11,13,14)あ るいは DTT ${ }^{12,18)}$ の使用例が報告されているが，後者の 方が移動相溶媒に対する溶解性が非常によかったため, 今回は DTTを用いて還元を行った。

還元操作は「実験方法」に示したとおりとしたが，実 際に DHAA から AA への還元が行われるかどらかにつ いて, DHAA と AA の各濃度を $50 \mathrm{ppm}$ として調製し た標準溶液（溶媒：移動相溶媒）を用いて確認した結果 を Fig. 2 に示す。Fig. 2 a に示したように, DHAA は $268 \mathrm{~nm}$ では汪とんとんど吸収を持たない。一方 DHAA と AA の等量混合物について, 上記の還元操作を行った 場合と行わなかった場合とで, 試料を HPLC に導入し て比較した結果，未処理試料 (Fig. 2 b) に比べて還元処 理試料 (Fig. 2 c) では AA のピーク面積が 1.97 倍に増 大したことから，実際にDHAA から AA への還元がほ ぼ完全に達成されていることが確認できた。

なお，このとき還元試液中の DTT が吸収を持たない ことは別途確認した。

また，今回は DHAA から AA への還元についてのみ 確認したが，過去の報告 ${ }^{12)}$ も併せて考慮し，今回の操作 で DHEA から EA への還元も同様に達成されるものと 判断した。

\section{Sep-pak カートリッジの選択}

本法では，ワイン試料中の色素やその他の夾雑物の除 去による分離カラムの負担減少を目的として, Sep-pak カートリッジによるクリーンアップを検討した。

過去の報告では, 食品中の AA 分析の際に Sep-pak $\mathrm{C}_{18}$ (オクタデシル基) カートリッジに試料を素通りさせ ることでクリーンアップを行っている例 ${ }^{3,4,10,13,15)}$ が多 々見受けられる。しかしながら本法では分析対象が 3 成

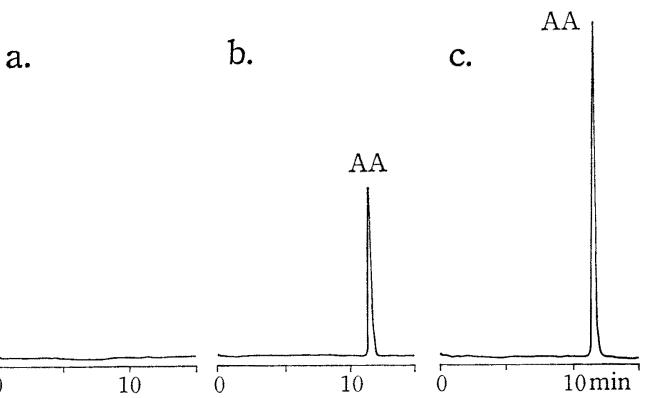

Fig. 2 Effect of reduction from dehydroa scorbic acid (DHAA) to A by 10 $\mathrm{mM}$ dithiothreitol (DTT).

a : Chromatogram of DHAA standard (50ppm)

b : Chromatogram of DHAA and AA standard (50ppm, respectively)

c : Chromatogram of $\mathrm{b}$ after reduction by $10 \mathrm{~mm}$ DTT
分であるため, まず最適の Sep-pak を選択・決定する 必要がある。その際の十分条件としては, 目的の 3 成分 は吸着しないが， 3 成分以外の夾雑物は吸着・除去する 性質を持つものでなければならない。そこで $\mathrm{C}_{18}$ の他に $\mathrm{CN}$ (シアノプロピル基), accell CM (カルボキシメチル 基) の 3 種類の Sep-pak についてクリーンアップ効果 を比較検討した。まず, $\mathrm{AA}, \mathrm{EA}, \mathrm{SA} の 3$ 成分を全く含 有しない赤ワインに，濃度が $100 \mathrm{ppm}$ となるよらに各 成分を添加した標準溶液を調製した。次に，「実験方法」 に示した操作どおりに各 Sep-pak によるクリーンアッ プと還元処理を行った後, HPLC に導入し, 各 Seppak 処理が試験溶液中の各成分濃度に及ぼす効果につい て比較した。結果を Table 1 に示す。AA と EA はい ずれの Sep-pak にも吸着されずに溶出したが, SA は Sep-pak $\mathrm{C}_{18}$ にほとんど吸着された。すなわち本法では Sep-pak $\mathrm{C}_{18}$ は使用に適さないことが判明した。

一方, Sep-pak CN ならびに accell CM の比較で は,クロマトグラム上でほとんど差異は認められなかっ たが，目視的には前者のほらがより多くの色素や共雑成 分を吸着除去していると判断できたため，以降の実際の ワイン試料のクリーンアップには Sep-pak CN を採用 することとした。

Table 1 Concentration of each additive in flow-through fraction after Sep-pak treatment.

\begin{tabular}{l|r|r|r}
\hline \multirow{2}{*}{ Sep-pak } & \multicolumn{3}{|c}{ concentration (ppm) } \\
\cline { 2 - 4 } & AA & EA & S A \\
\hline C18 & 98.3 & 98.2 & 11.2 \\
CN & 103.1 & 101.7 & 97.3 \\
accell CM & 98.9 & 100.2 & 99.2 \\
\hline
\end{tabular}

* Concentration of each additive before Sep-pak treatment is $100 \mathrm{ppm}$, respectively.

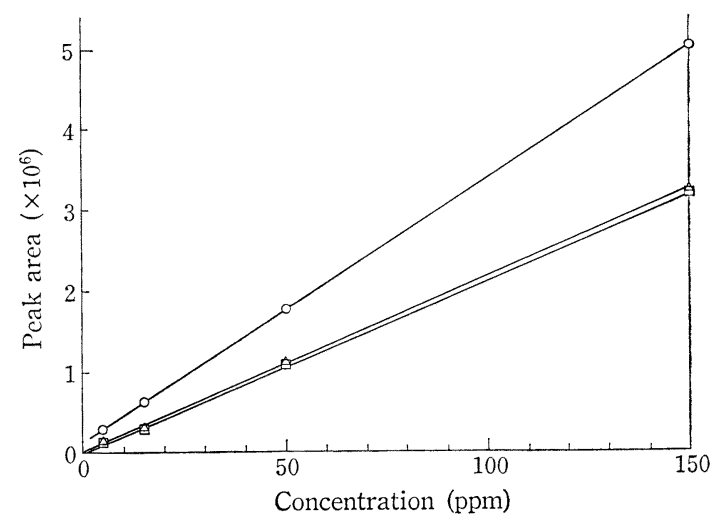

Fig. 3 Calibration curves of AA $(\square)$, EA $(\triangle)$, and $\mathrm{SA}(\mathrm{O})$. 
柳田・橋本・黄木 : 高速液体クロマトグラフィーによるワィン中の総アスコルビン酸等の同時迅速定量法

Table 2 The contents of total AA, total EA and SA in imported wines.

\begin{tabular}{|c|c|c|c|c|c|c|c|c|c|c|c|c|c|c|}
\hline No. & $\begin{array}{c}\text { country*1 } \\
\text { (wine type*2) }\end{array}$ & $\begin{array}{c}\text { Total } \\
\text { AA }\end{array}$ & $\begin{array}{c}\text { Total } \\
\text { EA }\end{array}$ & S A & No. & $\begin{array}{c}\text { country*1 } \\
\text { (wine type*2) }\end{array}$ & $\begin{array}{l}\text { Total } \\
\text { AA }\end{array}$ & $\begin{array}{c}\text { Total } \\
\text { EA }\end{array}$ & S A & No. & $\begin{array}{c}\text { country }{ }^{* 1} \\
\text { (wine type*2) }\end{array}$ & $\begin{array}{c}\text { Total } \\
\text { AA }\end{array}$ & $\begin{array}{c}\text { Total } \\
\mathrm{EA}\end{array}$ & SA \\
\hline 1 & $F(W)$ & 30.6 & & & 11 & $F(R)$ & 28.7 & & & 21 & $\mathrm{G}(\mathrm{W})$ & & & 111.7 \\
\hline 2 & $F(W)$ & 25.0 & & & 12 & $F(R S)$ & & & 155.4 & 22 & $A(W)$ & 12.9 & 76.5 & \\
\hline 3 & $\mathrm{~F}(\mathrm{~W})$ & 17.5 & & & 13 & $F(R S)$ & & & 124.2 & 23 & $\mathrm{P}(\mathrm{W})$ & & & 90.0 \\
\hline 4 & $F(W)$ & 10.1 & & 108.0 & 14 & $F(S)$ & 32.4 & & & 24 & $\mathrm{C}(\mathrm{W})$ & & & 158.5 \\
\hline 5 & $\mathrm{~F}(\mathrm{~W})$ & & 4.8 & 9.7 & 15 & $F(S)$ & 17.8 & & & 25 & $\mathrm{C}(\mathrm{W})$ & & & 151.5 \\
\hline 6 & $F(W)$ & & & 145.4 & 16 & $G(W)$ & & & 156.2 & 26 & $\mathrm{C}(\mathrm{W})$ & & & 92.0 \\
\hline 7 & $F(W)$ & & & 132.9 & 17 & $\mathrm{G}(\mathrm{W})$ & & & 151.4 & 27 & $C(R)$ & & & 166.3 \\
\hline 8 & $F(W)$ & & & 128.1 & 18 & $\mathrm{G}(\mathrm{W})$ & & & 142.6 & 28 & $C(R)$ & & & 71.0 \\
\hline 9 & $F(W)$ & & & 118.4 & 19 & $\mathrm{G}(W)$ & & & 136.3 & 29 & $\mathrm{C}(\mathrm{RS})$ & & & 66.4 \\
\hline 10 & $\mathrm{~F}(\mathrm{~W})$ & & & 7.7 & 20 & $\mathrm{G}(\mathrm{W})$ & & & 131.1 & 30 & $\mathrm{C}(\mathrm{B})$ & & & 166.8 \\
\hline
\end{tabular}

*1 F : France, G : Germany, A : Austria, P : Portugal, C : California, U.S. A.

*2 W : White type, R: Red type: RS : Rose type, B : Blush type, S: Sparkling type

\section{4. 検量線の作成}

$\mathrm{AA}, \mathrm{EA}, \mathrm{SA}$ の 3 成分を全く含有しない赤ワインに, 濃度が $5, \quad 50,100$ ならびに $150 \mathrm{ppm}(\mathrm{mg} / \mathrm{kg})$ となる ように各成分を添加した標準溶液を調製した。続いて, 各標準溶液に対し試料と同様の操作でクリーンアップな らびに還元処理を行った後, それぞれ HPLC へ導入し, ピーク面積法により検量線を作成したところ， $5 \mathrm{ppm}$ か ら 150 ppm の間でFig. 3 に示したとおり良好な直線性 が得られた。

\section{5. 分析精度ट定量限界}

本法では，試料調製に際して 1) Sep-pak CN による クリーンアップ時の各成分の濃度減少がほとんどないこ と，2）DTTによる還元がほぼ完全に行われていること を前述のとおり確認した。さらに検量線を，赤ワイン に各成分の既知量を添加した標準溶液を試料と同様に Sep-pak CN 処理，DTT 還元を行ってから作成したの で，本法に関してはあらためて添加回収率を求める必要 はないものと判断した。

なお，赤ワインに各成分を $50 \mathrm{ppm}$ 添加した標準溶液 を用いて分析精度を検討した結果, 5 回の繰り返し測定 で定量值の变動係数は AA が $2.7 \%$, EA が $2.0 \%$, SA が 3.5\% であった。

また本条件に基づく HPLC の検出限界は AA, EA が $2 \mathrm{ppm}, \mathrm{SA}$ が $1 \mathrm{ppm}$ であり, 定量限界はいずれも 3 $\mathrm{ppm}$ であった。本法は蛍光法 ${ }^{5 \sim 10)}$ と比べると感度的に劣 るのが欠点であるが， ワインや食品中の添加物分析の目 的で適用する場合, 十分な測定感度を有していると判断 できる。

\section{6. 市販試料への応用}

本法を市販ワイン（輸入品）試料に適用し総 $\mathrm{AA}$, 総 EA ならびに SA の分析を試みた。その結果, 今回測定 した 95 製品中 30 製品から 3 成分のいずれかが検出さ れた。この 30 製品の分析結果を Table 2 に示した。ま た，その代表的なクロマトグラムを Fig. 4 に示した。
30 製品中 $\mathrm{AA}$ が検出されたのは 8 製品であり,これ らの製品では AA が酸化防止の用途で添加されている 可能性がある。EA は 2 製品から検出され, そのうち 1 製品は $76.5 \mathrm{ppm}$ と高含量であった。 SA は23 製品か ら検出されたが，我が国の最大使用基準である $200 \mathrm{ppm}$ を超えて添加されているような製品は見あたらなかっ た。

なお，本法による測定の前処理の際に，DTT による 還元処理を行わずに HPLC 测定することで, 試料中の 還元型の AA， EA のみを検出検定することが可能であ る。この場合，さらに通常の還元処理を行って得られた 総 $\mathrm{AA}$ あるいは総 $\mathrm{EA}$ の定量值から還元型 AA あるい は還元型 EA の值を差し引くことで, DHAA あるいは DHEA の值も算出できる。Table 2 に示したワインのう ち， $\mathrm{AA}$ あるいは $\mathrm{EA}$ が検出された製品について上記の 追試・計算を行い，総 $\mathrm{AA}$ 量に対する還元型 $\mathrm{AA}$ と DHAA の量および割合, ならびに総 EA 量に対する還 元型 EA と DHEA の量および割合を求めた。結果を Table 3 に示した。

これより, 若干の例外は認められるものの, ワイン中 に拈いて AA ならびに EA は大部分が還元型で存在す ることがわかった。

\section{要 約}

HPLC/UV 検出法によるワイン中の総 $\mathrm{AA}$, 総 EA な らびに SA の同時迅速定量法を確立した。ワイン試料を Sep-pak CN カートリッジに素通りさせてクリーンアッ プした後，DTTによる還元処理を行うことで試料中の DHAA と DHEA をそれぞれ UV 吸収を持つ AA と $\mathrm{EA}$ へと転換した。この試料を HPLC へ導入し， AA, $\mathrm{EA}, \mathrm{SA}$ の 3 成分をクロマト分離してそれぞれのピーク 面積を測定することで同時定量を行った。本法の検出限

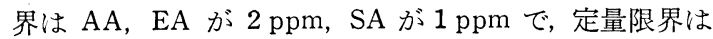
$\mathrm{AA}, \mathrm{EA}, \mathrm{SA}$ のいずれも $3 \mathrm{ppm}$ であった。また, 各成 


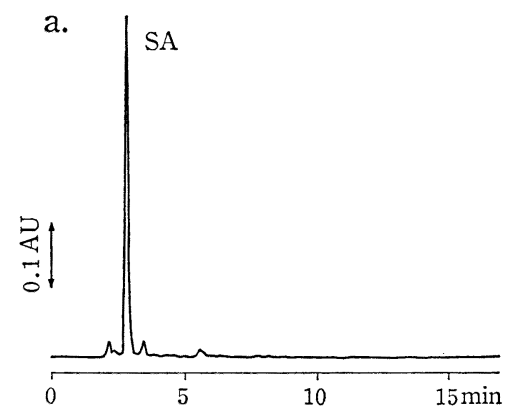

b.

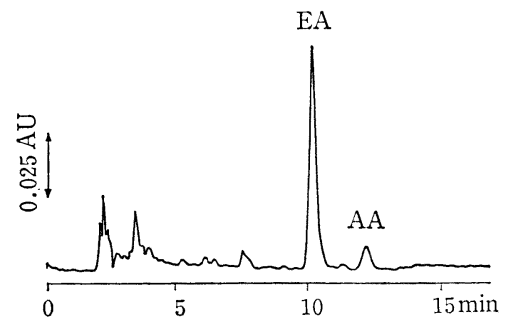

Fig. 4 Chromatogram of market wine.

a : An example of french wine (rose type) which contained SA

$\mathrm{b}$ : example of austrian wine (white type) which contained AA and EA

Table 3 Contents of reduced and oxidized forms of AA and EA in imported wines.

\begin{tabular}{c|c|c|c|c|c|c|c}
\hline \hline No. & $\begin{array}{c}\text { country*1 } \\
\text { (wine type*2) }\end{array}$ & $\begin{array}{c}\text { AA } \\
(\mathrm{ppm})\end{array}$ & $\begin{array}{c}\text { DHAA } \\
(\mathrm{ppm})\end{array}$ & $\begin{array}{c}\% \text { of AA in } \\
\text { total AA }\end{array}$ & $\begin{array}{c}\text { EA } \\
(\mathrm{ppm})\end{array}$ & $\begin{array}{c}\text { DHEA } \\
(\mathrm{ppm})\end{array}$ & $\begin{array}{c}\text { \% of EA in } \\
\text { total EA }\end{array}$ \\
\hline 1 & $\mathrm{~F}(\mathrm{~W})$ & 28.9 & 1.7 & 94.4 & & & \\
2 & $\mathrm{~F}(\mathrm{~W})$ & 15.4 & 9.6 & 61.6 & & & \\
3 & $\mathrm{~F}(\mathrm{~W})$ & 15.1 & 2.4 & 86.3 & & & \\
4 & $\mathrm{~F}(\mathrm{~W})$ & 7.4 & 2.7 & 73.3 & & & \\
5 & $\mathrm{~F}(\mathrm{~W})$ & & & & 4.7 & 0.1 & \\
11 & $\mathrm{~F}(\mathrm{R})$ & 25.9 & 2.8 & 90.2 & & & \\
14 & $\mathrm{~F}(\mathrm{~S})$ & 30.5 & 1.9 & 94.1 & & & \\
15 & $\mathrm{~F}(\mathrm{~S})$ & 17.0 & 0.8 & 95.5 & & & \\
22 & $\mathrm{~A}(\mathrm{~W})$ & 12.2 & 0.7 & 94.6 & 71.3 & 5.2 & 93.2 \\
\hline
\end{tabular}

${ }^{* 1} \mathrm{~F}:$ France, A : Austria

${ }^{* 2} \mathrm{~W}:$ White type, $\mathrm{R}:$ Red type, $\mathrm{S}:$ Sparkling type

分の定量值の変動係数は $2.0 \sim 3.5 \%$ であり，良好な再 現性を示した。さらに本法を市販輸入ワインに適用した 結果, ワインに括ける酸化防止剤 (AA， EA) の使用状 況に関する新たな知見を得ることができた。

本研究遂行にあたり，有益なる御助言をいただきまし た国税庁醸造試験所第 3 研究室長戸塚昭博士に深謝致し ます。

\section{文献}

1）岩尾裕之, 高居百合子(編)：ビタミンの分析 p. 83, 講談社 (1972)

2) R. C. Rose, D. L. NAHrwold : Anal. Biochem., 114, 140 (1981)

3) J. W. Finley, E. DUANG : J. Chromatogr., 207, 449 (1981)

4) P. Wimalasiri, R. B. H. Wills : J. Chromatogr., 256, 368 (1983)

5) R. W. Keating, P. R. HAdDAD : J. Chromatogr., 245, 249 (1982)

6) J. T. VAnderslice, D. J. Higgs : J. Chromatogr. Sci., 22, 485 (1984)

7) A. J. SPEEK, J. SCHRIJVER, W. H. P. SCHREURS :

J. Agric. Food Chem., 32, 352 (1984)

8) B. KaCEM, M. R. MARShall, R. F. MatThews,
J. F. Gregory : J. Agric. Food Chem., 34, 271 (1986)

9) A. Lopez-Anaya, M. Mayersohn : Clin.Chem., 33, 1874 (1987)

10）林 弘道, 宮川あし子：食衛誌，31, （1）44 (1990)

11) D. B. Dennison, T. G. BRAWLEY, G. L. K. Hunter: J. Agric. Food Chem., 29, 927 (1981)

12) L. W. Doner, K. B. HiCKs : Anal. Biochem., 115, 225 (1981)

13) D. E. GOODNEY : J. Chem. Ed., 64, 187 (1987)

14) C. LAvigne, J. A.ZOE : J. Chromatogr., 410, 201 (1987)

15）北田 善三, 玉瀬 喜久雄, 佐々木美智子, 山添 胜：日食工誌, 36,62 (1989)

16) Extrait du Codex cenologique international de l'O.I.V., P. 31, Office International de la Vigne et du Vin, Paris (1978)

17) E. VOGT, H. BIEBER : Weinchemie und Wienanalyse, p.338, Verlag Eugen Ulmer, Stuttgart (1970)

18) H-J. KIM : J. Assoc. Off. Anal. Chem., 72, (4) 681 (1989) 